\title{
Roche HPV Lab Test
}

National Cancer Institute

\section{Source}

National Cancer Institute. Roche HPV Lab Test. NCI Thesaurus. Code C157414.

A human papilloma virus test developed by Roche laboratories. 